\title{
IDENTIFIKASI FAKTOR-FAKTOR YANG MEMPENGARUHI KESIAPAN KERJA SISWA TEKNIK PERBAIKAN BODI OTOMOTIF
}

\author{
Suryadi M. Syarip ${ }^{1}$, Amay Suherman ${ }^{2}$ Yayat $^{3}$ \\ Universitas Pendidikan Indonesia \\ Jl. Dr. Setiabudi No. 229 Bandung 40154 \\ suryadims@gmail.com
}

\begin{abstract}
ABSTRAK
Tujuan penelitian ini untuk mengetahui faktor dominan yang mempengaruhi kesiapan kerja siswa kelas TPBO SMKN 8 Bandung. Penelitian ini menggunakan metode penelitian deskriptif dengan pendekatan kuantitatif. Populasi dalam penelitian ini adalah siswa kelas XII TPBO SMKN 8 Bandung. Sampel diambil dengan teknik quota sampling dengan jumlah sampel 60 siswa. Hasil penelitian berdasarkan analisis faktor bahwa ada 2 faktor yang memengaruhi kesiapan kerja siswa. Kedua faktor tersebut adalah (1) motivasi belajar, pengalaman praktik luar, bimbingan vokasional, dan ekspektasi masuk dunia kerja, (2) informasi pekerjaan, teman sebaya, dan kesempatan mendapatkan kemajuan. Faktor yang paling dominan memengaruhi kesiapan kerja siswa dalam bidang teknik perbaikan bodi otomotif yaitu: motivasi belajar, pengalaman praktik luar, bimbingan vokasional, dan ekspektasi masuk dunia kerja.
\end{abstract}

Kata kunci: kesiapan kerja, bodi otomotif, faktor dominan.

\section{PENDAHULUAN}

SMK Negeri 8 Bandung sebagai sekolah yang mendidik siswa untuk berkompetensi khususnya di bidang otomotif, selalu mengedepankan bagaimana siswa harus berprestasi dan mempunyai skill untuk menjadi bekal setelah lulus nanti. Bekal tersebut menjadi modal penting untuk siswa dalam terjun ke dunia kerja atau berwirausaha. Harapan yang sedemikian baik tidak sejalan dengan fakta di lapangan. Padahal, penyelenggaraan pendidikan SMK di Indonesia memberikan keleluasaan untuk bekerja bagi siswa setelah lulus (Anoraga, 2006). Ukuran kinerja untuk mengembangkan mutu dan relevansi SMK, siswa setalah lulus diantaranya: (1) Siswa dapat bekerja, dengan persentase $40 \%$ bisa terserap di dunia kerja dan relevan dengan kompetensi kerjanya, (2) siswa dapat dapat bekerja di luar negeri dengan persentase 5\%, (3) siswa dapat bekerja tidak sesuai dengan bidang keahliannya dengan presentase $10 \%$, (4) siswa dapat melanjutkan pendidikan dengan presentase 10\%, (5) dan Siswa dapat berwirausaha, dengan persentase 35\%.

Hasil wawancara ke industri/perusahaan perbaikan bodi yaitu di AUTO2000 Bodi dan Cat Cibiru, memperkuat masalah yang sedang terjadi pada lulusan TPBO. Informasi yang diperoleh salah satunya keluhan dari pihak perusahaan adalah kompetensi siswa yang tidak sesuai harapan. Setelah diamati dari pihak perusahaan ke sekolah ternyata masalah yang

\footnotetext{
${ }^{1}$ Mahasiswa Departemen Pendidikan Teknik Mesin FPTK UPI

2 Dosen Departemen Pendidikan Teknik Mesin FPTK UPI

${ }^{3}$ Dosen Departemen Pendidikan Teknik Mesin FPTK UPI
} 
terjadi banyak sekali (Supriatna, 2006). Masalah utama yang menjadi perhatian diantaranya: mulai dari proses pembelajaran, kegiatan praktikum yang tidak terkondisikan dengan baik, alat dan kelengkapan praktikum yang tidak memadai, serta minat belajar siswa yang sangat kurang. Sekolah yang menyelenggarakan jurusan TPBO harus ada pembenahan dalam menyiapkan lulusan secara terstruktur (Dalyono, 2009). Faktor-faktor yang mempengaruhi terhadap permasalahan pengangguran pada lulusan SMK 8 Bandung untuk program keahlian TPBO ini (Yunita, et. al, 2013). Kemungkinan karena kesiapan kerja yang tidak terasah pada saat di sekolah. Masalah tersebut sangat tidak diharapkan terjadi pada lulusan siswa TPBO oleh pihak manapun, khususnya sekolah sebagai penanggung jawab penyelenggara program keahlian TPBO (Fitriyanto, 2006).

Kesiapan (readiness) merupakan penyesuaian kondisi pada suatu saat akan berpengaruh pada atau kecenderungan untuk memberi respons (Slameto, 2013). Kesiapan kerja adalah suatu kemampuan seseorang untuk menyelesaikan pekerjaan sesuai dengan ketentuan tanpa mengalami kesulitan dan hambatan dengan hasil yang maksimal dan sesuai target yang ditentukan. Kesiapan kerja ditentukan oleh dua faktor, yaitu: faktor internal (pengaruh yang berasal dari dalam diri seseorang), dan faktor eksternal (pengaruh yang berasal dari luar) (Kwok, 2014).

\section{METODE PENELITIAN}

Penelitian ini menggunakan metode deskriptif. Peneliti tidak melakukan manipulasi atau memberikan perlakuan-perlakuan tertentu terhadap objek penelitian, kegiatan atau peristiwa bejalan seperti apa adanya. Penelitian deskriptif ini menggunakan pendekatan kuantitatif, karena pengumpulan data menggunakan angka-angka dan setelah itu dijabarkan secara deskriptif. Penelitian ini akan dilakukan terhadap siswa kelas XII program keahlian TPBO pada tahun ajaran 2017/2018 di SMKN 8 Bandung.

Instrumen yang digunakan yaitu angket. Angket yang telah dilengkapi dengan alternatif jawaban dan responden hanya memilih jawabannya. Pengukuran pada variabel kesiapan kerja menggunakan skala Guttman. Penggumpulan data mengunakan skala Guttman karena dengan anggapan bahwa subjek adalah orang yang paling tahu tentang dirinya sendiri serta memberikan jawaban yang tegas terhadap suatu permasalahan yang dinyatakan.

Variabel terikat dalam penelitian ini adalah kesiapan kerja siswa program keterampilan. Komponen variabel tersebut diantaranya (1) motivasi belajar, (2) pengalaman praktek luar, (3) bimbingan vokasional, (4) bimbingan dari orang tua, (5) prestasi belajar 
sebelumnya, (6) informasi pekerjaan, dan (7) ekspektasi masuk dunia kerja, (8) Gaji, (9) kesempatan mendapatkan kemajuan, dan (10) teman sebaya. Teknik analisis data yang digunakan dalam penelitian ini adalah analisis faktor. Analisis faktor adalah suatu teknik analisis statistika multivariat yang berfungsi untuk mereduksi dimensi data dengan cara menyatakan variabel asal sebagai kombinasi linear sejumlah faktor umum atau common factor.

\section{HASIL PENELITIAN}

Uji kelayakan data dilakukan untuk melihat apakah data yang diperoleh layak untuk diolah dengan menggunakan anlisis faktor. Hal ini dapat diketahui dengan menggunakan uji KMO dan uji Bartlett. Apabila nilai KMO lebih dari 0,5 dan uji Bartlett dengan signifikansi dari kesalahan yang ditentukan. Hasil perhitungan diperoleh nilai KMO sebesar 0,701. Hasil perhitungan tersebut menunjukkan bahwa data tersebut layak untuk dianalisis ke tahap analisis faktor. Pengujian KMO dan barlett ini merupakan pengujian keempat, karena variabel prestasi belajar, gaji, dan bimbingan orang tua pada pemilihan sebelumnya nilai MSA-nya kurang dari 0,5.

Data yang sudah layak dianalisis, kemudian dilakukan analisis nilai MSA pada masing-masing variable. Hasil perhitungan, bahwa nilai MSA untuk masing masing variabel adalah: 0,650 (motivasi belajar); 0,710 (pengalaman praktik luar); 0,705 (bimbingan vokasional); 0,788 (informasi pekerjaan); 0,715 (ekspektasi masuk dunia kerja); 0,626 (teman sebaya); dan 0,704 (kesempatan mendapatkan kemajuan). Hasil analisis menunjukkan nilai MSA pada masing-masing variabel sudah memenuhi syarat, yaitu nilai MSA > 0,5. Variabel yang sudah memenuhi persyaratan ini, akan dilanjutkan ke proses analisis faktor.

Nilai extraction merupakan nilai yang menunjukan kontribusi variabel tersebut terhadap faktor yang terbentuk atau besaran nilai varian (dalam persentase) suatu variabel yang dapat dijelaskan oleh faktor yang terbentuk. Sebagai contoh, variabel motivasi belajar dengan nilai extraction 0,49 menunjukkan bahwa variabel motivasi belajar memberikan kontribusi terhadap faktor yang terbentuk sebesar 0,494 atau 49,4\%.

Variabel yang dimasukan dalam analisis faktor ada tujuh variabel, yakni: motivasi belajar, pengalaman praktik luar, bimbingan vokasional, informasi pekerjaan, ekspektasi masuk dunia kerja, teman sebaya, dan kesempatan mendapatkan kemajuan. Hanya ada dua faktor yang terbentuk, yaitu: (1) faktor kesatu dengan angka eigenvalues sebesar 2,43. Faktor kedua dengan angka eigenvalues sebesar 1,13. Sebuah variabel dapat dijadikan sebuah faktor 
apabila angka atau nilai eigenvalue-nya di atas 1 (Santoso, 2017). Scree plot merupakan alat untuk memperjelas terbentuknya faktor dari total variance explained. Hal tersebut untuk mempertegas dari ketujuh variabel yang membentuk suatu faktor yang dominan terhadap kesiapan kerja siswa. Faktor yang terbentuk hanya ada dua component number yang memiliki nilai eigenvalue di atas 1.

Ada dua faktor yang terbentuk. Apabila suatu variabel mempunyai nilai loading factor terbesar pada faktor tertentu, maka variabel tersebut akan menjadi anggota atau pembentuk faktor tersebut. Variabel informasi pekerjaan, korelasi antara variabel tersebut dengan kedua faktor cukup kuat dengan nilai loading factor satu sebesar 0,53 dan angka nilai loading factor dua sebesar 0,42. Selisih korelasi yang terlalu kecil tersebut harus dilakukan proses rotasi faktor agar semakin jelas perbedaan sebuah variabel yang akan dimasukan kedalam salah satu faktor yang terbentuk.

Component matrix hasil dari proses rotasi (rotated component matrix) memperlihatkan distribusi variabel yang lebih jelas dalam korelasi antara variabel dari komponen satu dan komponen dua, artinya variabel yang masuk dalam salah satu faktor mempunyai perbedaan nilai yang signifikan. Hasil component matrix hasil dari proses rotasi memperlihatkan distribusi variabel yang lebih jelas dan nyata. Variabel informasi pekerjaan setelah dirotasi, masuk ke dalam faktor dua dengan nilai korelasi yang kuat sebesar 0,62. Hasil component transformation matrix dari nilai yang terbentuk secara diagonal pada komponen 1 dan komponen $2(0,78$ dan 0,78$)$ menunjukkan kedua komponen yang terbentuk sudah tepat, karena mempunyai korelasi yang tinggi antara faktor sebelum dirotasi dan faktor yang sudah dirotasi.

\section{PEMBAHASAN}

Sebanyak 10 variabel yang diteliti tentang kesiapan kerja, hanya ada 7 (tujuh) variabel yang muncul. Ketiga variabel yang tidak muncul pada saat proses analisis. Variabel tersebut tidak terlalu mempengaruhi terhadap kesiapan kerja siswa kelas XII TPBO. Tujuh variabel yang muncul merupakan variabel yang dominan atau yang mempunyai peran atas kesiapan kerja siswa, ketujuh variabel tersebut yaitu: (1) motivasi belajar, (2) pengalaman praktik luar, (3) bimbingan vokasional, (4) ekspektasi masuk dunia kerja, (5) informasi pekerjaan, (6) teman sebaya, dan (7) kesempatan mendapatkan kemajuan. Variabel yang dominan ini menghasilkan 2 (dua) faktor yang terbentuk, faktor yang terbentuk diberi nama sesuai dengan variabel yang mengelompok pada faktor tersebut, yaitu: faktor 1 (satu) dan faktor 2 
(dua). Faktor tersebut masing-masing mempunyai nilai yang dapat menjelaskan peran faktor tersebut terhadap kesiapan kerja siswa TPBO SMKN 8 Bandung.

Faktor pertama yang terdiri dari motivasi belajar, pengalaman praktik luar, bimbingan vokasional, dan ekspektasi masuk dunia kerja adalah yang mempengaruhi kesispan kerja siswa (Purwanto, 2006). Faktor ini memberikan kontribusi sebesar 34,69\% terhadap kesiapan kerja siswa kelas XII TPBO SMKN 8 Bandung. Variabel-variabel dalam faktor ini mempunyai faktor loading antara 0,578 sampai 0,73 yang berarti tingkat korelasi antar variabelnya adalah antara 57,8\% sampai $73 \%$. Korelasi terendah terletak pada variabel bimbingan vokasional dan korelasi tertinggi terletak pada variabel pengalaman praktik luar. Hasil penelitian ini menunjukkan bahwa variabel motivasi belajar, pengalaman praktik luar, bimbingan vokasional, dan ekspektasi masuk dunia kerja merupakan faktor yang mempengaruhi kesiapan kerja pada siswa TPBO SMKN 8 Bandung (Yusuf, S2006).

Faktor kedua yang mempengaruhi kesiapan kerja lulusan adalah variabel informasi pekerjaan, teman sebaya, dan kesempatan mendapatkan kemajuan. Faktor ini memberikan kontribusi sebesar $16,16 \%$ terhadap kesiapan kerja siswa kelas XII TPBO SMKN 8 Bandung. Faktor ini terdiri dari variabel-variabel dalam faktor ini mempunyai faktor loading antara 0,65 sampai 0,716 yang berarti tingkat korelasi antar variabelnya adalah antara $65,2 \%$ sampai $71,6 \%$. Korelasi terendah terletak pada variabel informasi pekerjaan dan korelasi tertinggi terletak pada variabel teman sebaya (Rahardjo, 2013). Hasil penelitian ini menunjukan bahwa variabel informasi pekerjaan, teman sebaya, dan kesempatan mendapatkan kemajuan merupakan faktor yang mempengaruhi kesiapan kerja pada siswa TPBO SMKN 8 Bandung.

Faktor dominan (sangat berpengaruh) terhadap kesiapan kerja faktor 1 (satu). Faktor 1 (satu) meliputi variabel motivasi belajar, pengalaman praktik luar, bimbingan vokasional, dan ekspektasi masuk dunia kerja. Program keahlian TPBO ini merupakan jurusan pada bidang otomotif yang bertujuan untuk memberikan bekal keahlian bagi siswa dalam perbaikan bodi otomotif, agar siswa siap terjun di dunia usaha maupun dunia kerja. Mempersiapkan siswa untuk terjun ke dunia kerja, sekolah dapat mempertimbangkan untuk mengembangkan ke dua faktor tersebut selama proses pembelajaran (Iskandar, et. al., 2016). Pencapaian dalam proses pembelajaran yang baik akan berdampak pada tingkat kesiapan kerja siswa yang lebih tinggi. Tingkat kesiapan kerja yang tinggi, siswa akan lebih mampu untuk menghadapi persaingan di dunia kerja. 


\section{KESIMPULAN}

Kesimpulan penelitian ini, sebagai berikut: ada dua faktor yang mempengaruhi kesiapan kerja siswa, yaitu adalah: faktor satu yang terbentuk dari variabel motivasi belajar, pengalaman praktek luar, bimbingan vokasional, dan ekspektasi masuk dunia kerja; dan faktor dua yang terbentuk dari variabel informasi pekerjaan, teman sebaya, dan kesempatan mendapatkan kemajuan. Faktor yang paling dominan mempengaruhi kesiapan kerja siswa adalah faktor satu yang terdiri dari motivasi belajar, pengalaman praktik luar, bimbingan vokasional, dan ekspektasi masuk dunia kerja.

\section{REFERENSI}

Anoraga, P. (2006). Psikologi Kerja. Jakarta: Rineka Cipta.

Dalyono. (2009). Psikologi Pendidikan. Jakarta: Rineka Cipta.

Fitriyanto, A. (2006). Ketidakpastian Memasuki Dunia Kerja karena Pendidikan. Jakarta: Dineka Cipta.

Iskandar, N., Setiawan, A., dan Sumardi, K. (2016). Identifikasi Faktor-Faktor Yang Mempengaruhi Siswa Smk Memilih Program Keahlian Teknik Mesin. Journal of Mechanical Engineering Education, 3(2), 220-224.

Kwok, D. (2014). International Conference on Teaching and Learning in Higher Education TLHE 2014. Work Readiness: A Study of Student Intern's Self-Perception and Supervisor Evaluation. Singapore: Center for Educational Development [Online] www.cdtl.nus.edu.sg/Tlhe/tlhe2014/abstracts/dkwok.pdf

Purwanto, M. N. (2006). Psikologi pendidikan. Bandung: PT. Remaja Rosdakarya.

Rahardjo, B. (2013). Analisis Faktor Untuk Mengetahui Pengaruh Personal Selling dan Word of Mouth terhadap Keputusan Pembelian Suatu Studi Kasus Pada PT. Starmas Inti Alumunium Industri. Jurnal Ekonomi dan Manajemen, 2(1), 1-19.

Slameto. (2013). Belajar dan Faktor-Faktor Yang Mempengaruhinya. Jakarta: Rineka Cipta.

Supriatna, M. (2006). Apa dan Bagaimana Bimbingan Karir. Bandung: Jurusan Pendidikan Psikologi dan Bimbingan.

Yunita, Sunardi, dan Dafik. (2013). Identifikasi Faktor Penyebab Rendahnya Penguasaan Materi dalam Ujian Nasional Matematika SMA/MA Program IPA Tahun Ajaran 2009/2010 di Kabupaten Jember Bagian Utara dan Timur. Jurnal Pancaran, 2(1), 197-208.

Yusuf, S. (2006). Psikologi Perkembangan Anak dan Remaja. Bandung: PT. Remaja Rosdakarya. 